\title{
STUDY THE WORKING OF PILES ON THE SLOPE GROUND SUBJECTED TO HORIZONTAL LOADING BY NUMERICAL SIMULATION METHOD
}

\author{
Nguyen Quoc Van*, Nguyen Thanh Sang, Trinh Trung Tien, \\ Nguyen Quy Thanh, Nguyen Thanh Nguyen, Le Ngoc Bin, \\ Cedric Sauzeat, Dang Van Tien
}

Le Quy Don Technical University, Hanoi, Vietnam

\author{
ARTICLE INFO \\ TYPE: Research Article \\ Received: 5/10/2020 \\ Revised: 30/10/2020 \\ Accepted: 6/11/2020 \\ Published online: 25/01/2021 \\ https://doi.org/10.47869/tcsj.72.1.7 \\ * Corresponding author \\ Email: nqvanvn@gmail.com; Tel: 0984555916
}

\begin{abstract}
Numerical modelling is an efficient method to investigate the effects of the distance from pile centreline to pile centreline on the working of laterally loaded piles considering the shear plastic deformations of the ground. The paper presents the research results the effects of piles spacing on the sloping ground including sand and clay layers subjected to horizontal loading according to the finite element method by ABAQUS software. Group of authors simulate the soil-pile interface, capable of incorporating the gapping and sliding in the soilpile interfaces for both sand and clay layers. The research results are used to predict the lateral load-deformation of piles for different cases and comparison with published research results. On that basis predicting the suitable distance horizontal loading piles that a pile negligible influenced from adjacent pile on a slope. This is a matter of high scientific and practical significance in foundation engineering in general, as well as in calculating pile foundations on a slopes in particular.
\end{abstract}

Keywords: horizontal loading, slope, horizontal displacement, ABAQUS, sand, clay, numerical simulation method, finite element method. 


\section{INTRODUCTION}

The piles subjected to lateral forces have been used for several complicated structures such as retaining walls, anchors, highways, abutments. Actually, these piles are usually working on the slope with different layered soil where the effect of slope is conjunction with lateral loading. [1-15] listed some criteria that the piles must satisfy including safety under loading, small enough deflection. Currently, the improved Winkler spring method is one of the most popular accepted design methods of laterally loaded piles on the horizontal surface in which the soil resistance is modeled by a number of soil springs along the pile, commonly known as p-y curves method. However the stiffness of these springs is assumed to be constant during analysis which is far from the actual working between pile and soil. The challenging escalated when not only pile on slope of layered soil but also the effect between neighbor piles. To address this problem, there have been a few investigations in the area of pile engineering, to obtain reliable solutions for the pile deformation under lateral loads on the layered slope (e.g. ) [2-15].

The system of pile-soil-pile interaction is complicated so the Winkler spring method is really difficult to meet the accurate requirement of calculation. Fortunately, numerical modeling with high performance computer facilities become more popular to solve the complex problems resulting the most accurate solutions in $3 \mathrm{D}$ analysis.

In this study, the response of a single pile and a row of three piles under lateral loading placed in the slope of layered sands and clays is numerically investigated using ABAQUS software version 6.20. The numerical modeling of a single pile are validated with the exiting field measurements reported by [11] for distances from pile centreline to the slope crest of 4D (where $\mathrm{D}$ is outside diameter of pile).

\section{FINITE ELEMENT ANALYSIS A ROW OF PILES ON THE SLOPE OF LAYERED SOIL}

The finite element commercial software ABAQUS version 6.20 and [1] has been used to simulate three dimensional behaviour of a single pile then a row of three piles on the slope. There were two parts, namely the pile and the layered soil for the single pile validating, while there were 4 parts soil and three piles in the row pile problems. Each part of soil is partitioned into sub-parts following the sand and clay layers. Material properties and interaction characteristics of each sand and clay layer is assigned to the model as in Table 1 which was reported by [11].

In order to allow gapping between the surounding soil and the piles, the shear strength of the interaction between the soil and the pile was defined by Mohr-Coulomb failure criterion (based on two soil properties, namely friction angle, $\varphi$ and cohesion, $\mathrm{c}_{\mathrm{u}}$ ). To do that, authors

had built a FORTRAN subroutine, called fric_coef, which has been adopted to include interaction between sand or clay with the piles.

The hollow steel pile was modeled as an isotropic elastic continuum while the soil was modelled as an isotropic elastic-perfectly plastic continuum with yielding described by the Mohr-Coulomb yielding criterion. Because the piles sitting on the slope so the effect of slope stability on the working of the pile while they were applied the same loading. 
Transport and Communications Science Journal, Vol. 72, Issue 1 (01/2021), 58-65

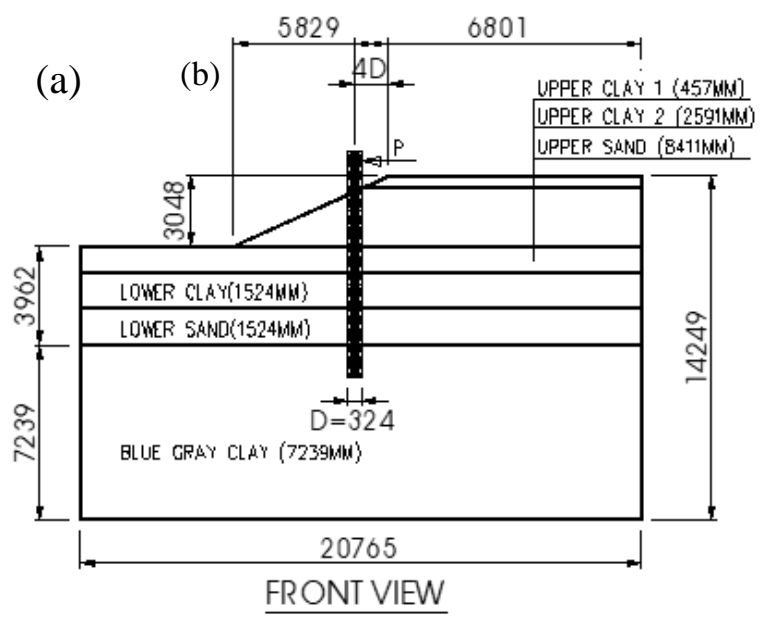

(b)
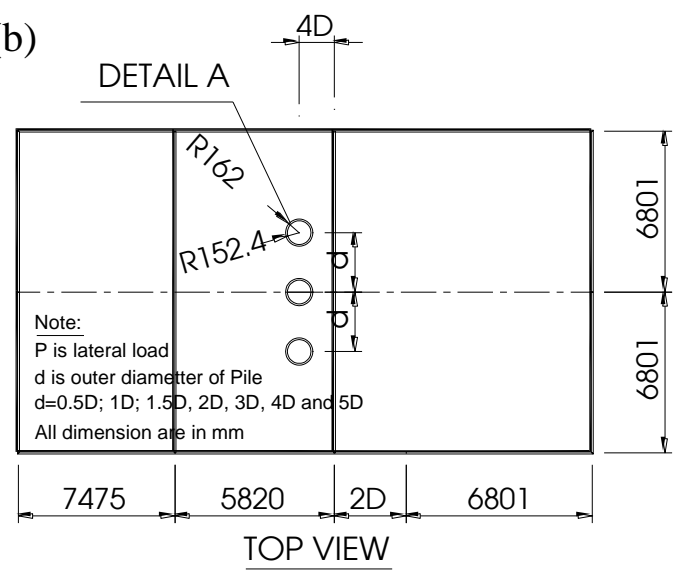

(c)

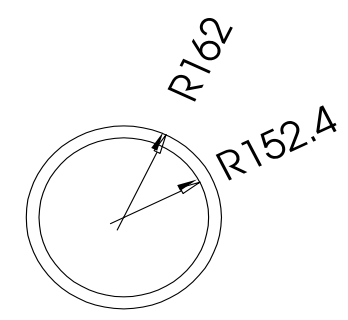

DETAIL A

Figure 1. Ground profile and the pile locations.

Boundary conditions were introduced by sets of vertical face and the bottom of the soil model in three dimensions. The bottom boundary is fixed against movements in all directions, whereas the ground surface is free to move in all directions. The vertical boundaries are fixed against movements in the direction normal to them.

The adopted mesh for the modelling of problem of three-dimensional single pile and three pile simulations under lateral loading in full model is illustrated in Figure 2(a) or 2(b). The mesh was selected based on the sensitivity study such that the computed results are not 
affected by the boundaries. As shown in Figure 2(c), The mesh was designed in such a way that it is finer near the pile surface and coarser away from the pile (the smallest soil mesh size was D/12 where D is outter pile diameter). Figure 2 (d) showed the same mesh size with the smallest dimension of pile thickness. The three dimensional element type used to simulate both the soil and the pile is the 10-node quadratic tetrahedron element (C3D10) resulting in the most stable solution without any solution convergence problem.

Table 1. Material properties of soil and pile adopted in the numerical simulation.

\begin{tabular}{|c|c|c|c|c|c|c|c|c|}
\hline Property & Unit & $\begin{array}{c}\text { Upper } \\
\text { clay 1 }\end{array}$ & $\begin{array}{c}\text { Upper } \\
\text { clay 2 }\end{array}$ & $\begin{array}{c}\text { Upper } \\
\text { sand }\end{array}$ & $\begin{array}{c}\text { Lower } \\
\text { clay }\end{array}$ & $\begin{array}{c}\text { Lower } \\
\text { sand }\end{array}$ & $\begin{array}{c}\text { Blue } \\
\text { gray } \\
\text { clay }\end{array}$ & Pile \\
\hline Thickness & $\mathrm{mm}$ & 457 & 2591 & 914 & 1524 & 1524 & 7239 & 9.525 \\
\hline Unit weight $\rho$ & $\mathrm{Kg} / \mathrm{m} 3$ & 1842.3 & 1842.3 & 2082.6 & 1842.3 & 2082.6 & 1762.2 & 8000 \\
\hline $\begin{array}{c}\text { Young Modulus } \\
\mathrm{E}\end{array}$ & $\mathrm{MPa}$ & 43.092 & 28.728 & 28.728 & 22.983 & 28.728 & 22.983 & $1.96 \mathrm{e} 5$ \\
\hline \begin{tabular}{c} 
Poisson's ratio $\mu$ \\
\hline Cohesion $\left({ }^{{ }_{u}}\right)$
\end{tabular} & - & 0.495 & 0.495 & 0.35 & 0.495 & 0.35 & 0.495 & 0.2 \\
\hline Friction Angle $\varphi$ & degree & 0 & 0 & 40 & 0 & 45 & 0 & - \\
\hline $\begin{array}{c}\text { Dilation Angle } \\
\psi\end{array}$ & degree & 0 & 0 & 0 & 0 & 0 & 0 & - \\
\hline
\end{tabular}

For modelling the lateral load which was applied to the head of the pile, there were a number of sub-step increment lateral displacement applied gradually to the pile head then the lateral reaction forces, stresses were recorded to calculate the equivalent lateral forces. The general static procedure is adopted under Steps option that allows automatic displacement increments for the user.

\section{RESULTS AND DISCUSSION}

\subsection{Verifying the numerical model with experiment of [11]}

Figure 3 summaries the pile head load-displacement curves obtained from both experimental of [11] and numerical investigations with ABAQUS for pile staying far from slope crest of $s=-4 D$. [11] did a wide range of field experiment for different distance from slope crest to pile centerline which are $\mathrm{s}=-4 \mathrm{D}, 0 \mathrm{D}, 2 \mathrm{D}, 4 \mathrm{D}$ and $8 \mathrm{D}$, where $\mathrm{D}$ is the outside diameter of the pile, but here the case s=-4D was taken into account to compare with validation case of a single pile (see Figure 1 and Figure 2).

It can be seen from Figure 3 that, the computed response from 3D finite element analyses is shown in Figure 3. The comparisons between the simulated outputs and measurements reveals that the results are in the recorded range. 
Transport and Communications Science Journal, Vol. 72, Issue 1 (01/2021), 58-65

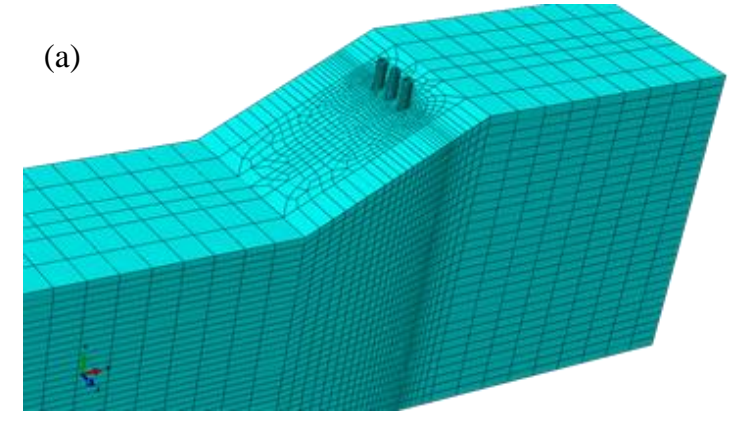

(b)
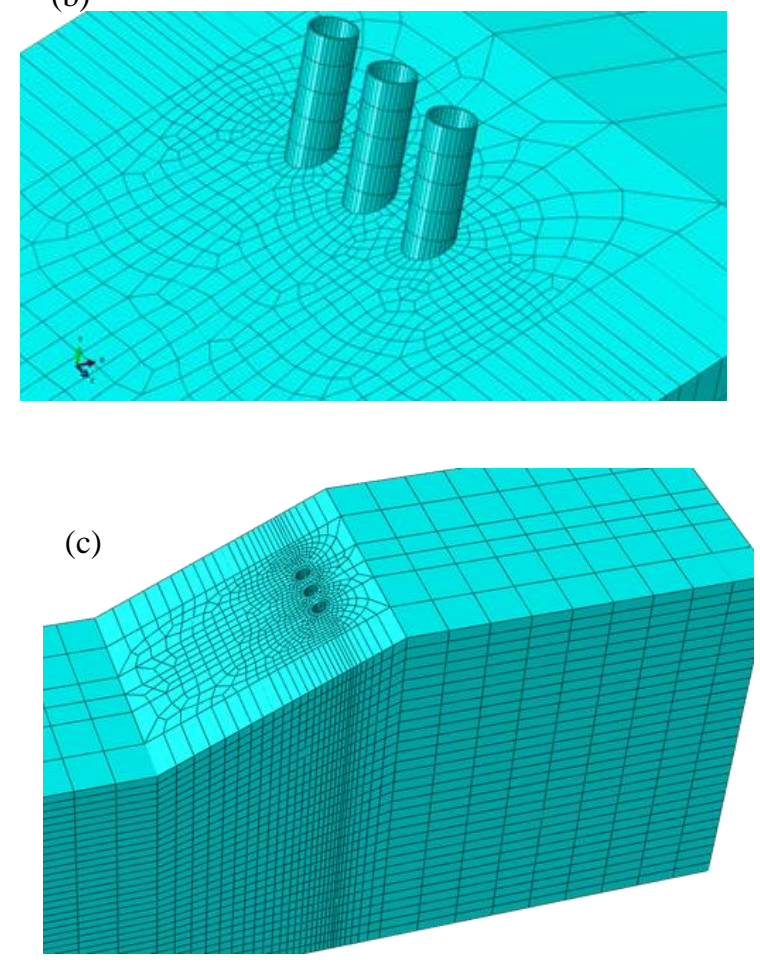

(d)

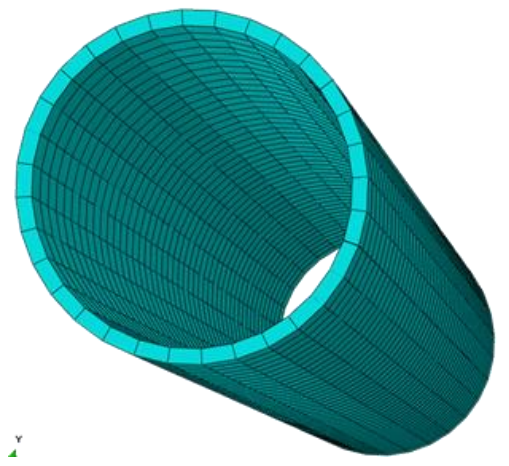

Figure 2. A typical adopted meshing scheme.

In the last paper of the same author, [12] has verified his numerical modelling with experimental work of [11]. They concluded that under the same pile and soil conditions, at the same pile head displacement, the lateral load response/resistance increases while the distance between the pile centreline and the slope crest (s) increases. As can be observed, the predicted pile head load-displacement curve at $\mathrm{s}=0 \mathrm{D}$ is postioned well below the curves for higher 
Transport and Communications Science Journal, Vol. 72, Issue 1 (01/2021), 58-65

values of s (e.g. 4D and 8D). This can calibrate the numerical modelling is acceptable to do further investigations.

\subsection{Predict minimum distance among piles in a row}

In this study, a row of three identical piles placing along the slope crest is investigated to find the effect of pile intervals on pile performance. Within this row, the center pile will be compared with the single pile case, the external piles performance was assumed the same that of the pile in the single pile case.

Figure 3 summaries the case study when the distance from the slope crest to the pile centre was $2 \mathrm{D}$ but there are six subcases have been compared. Case 1, single pile stayed only as previous investigation. Case 2, three piles stayed along the slope crest but the distance (d) between their centerline of the pile was 2D, Case 3, with distance of 3D and case 4 was 5D. All three piles were applied a displacement of $10 \mathrm{inch}(25.4 \mathrm{~mm})$ horizontally toward the slope crest. There results in Figure 3 show that the requirement loading of pile head are different from each other for each case.

When the pile head displacement is less than 5D, the all three displacements of pile head is less than that of the single pile (Case 1). This can conclude that the distance among the piles play an inportance role in the lateral loaded pile capacity. Therefore, to avoid the pile capacity losses in design, the piles should not be placed close to each other in horizontal or incline plane.

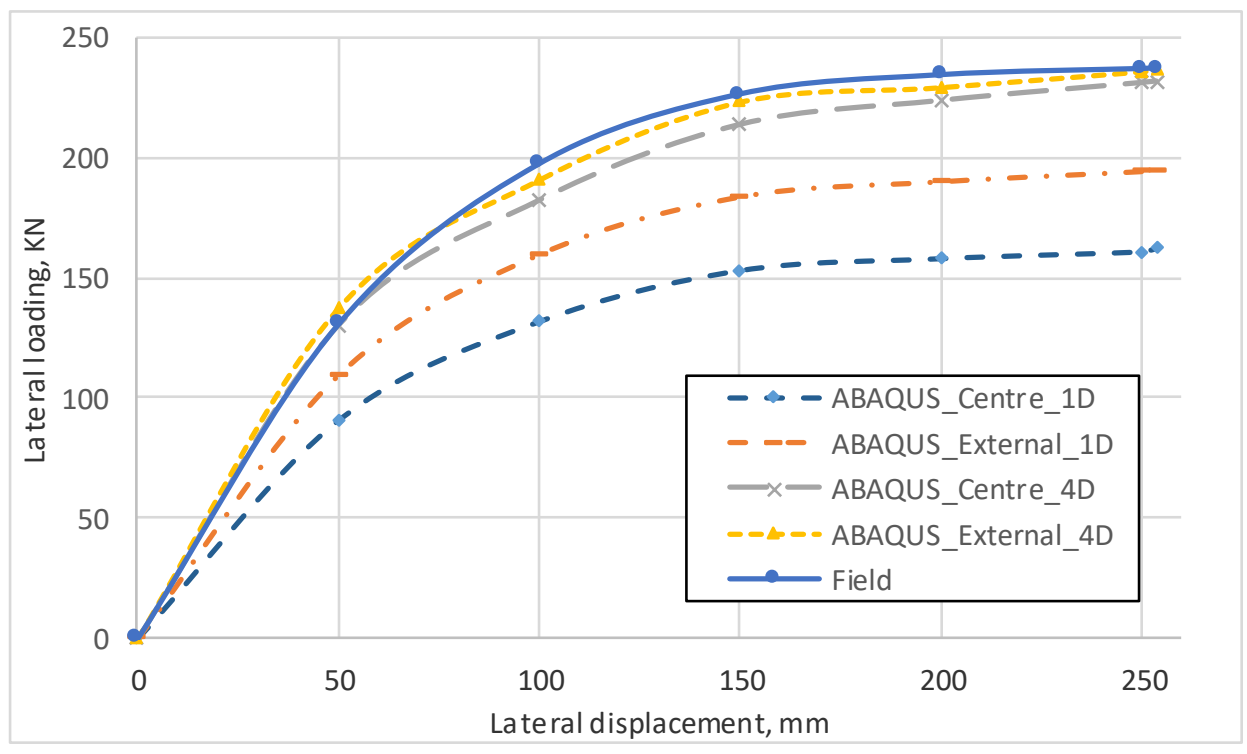

Figure 3. Load-Displacement curves from both filed measurements and numerical predictions.

In the case 2, the load displacement curve is much lower than Case 1, it reveals that, When the pile interval is too small i.e. $d=D$, the full pile lateral capacity is decreased by $33 \%$ as compared to single pile. The external pile also reduces lateral capacity of $12 \%$ due to the middle pile movement. When the distance among the pile increases, the lost of pile bearing 
Transport and Communications Science Journal, Vol. 72, Issue 1 (01/2021), 58-65

capacity under lateral loading reduces gradually. Moreover, the external pile lost bearing capacity less than the centre pile due to the far side of the external pile is intact soil when all three pile applied the same lateral loading.

For this case study of pile on the slope, the minimum distance between pile requires at least $d \geq 4 \mathrm{D}$ to ensure each pile has full capacity for lateral loading.

The numerical modelling can provide the best possible estimate for the minimum distance among the piles in a particular row.

(a)

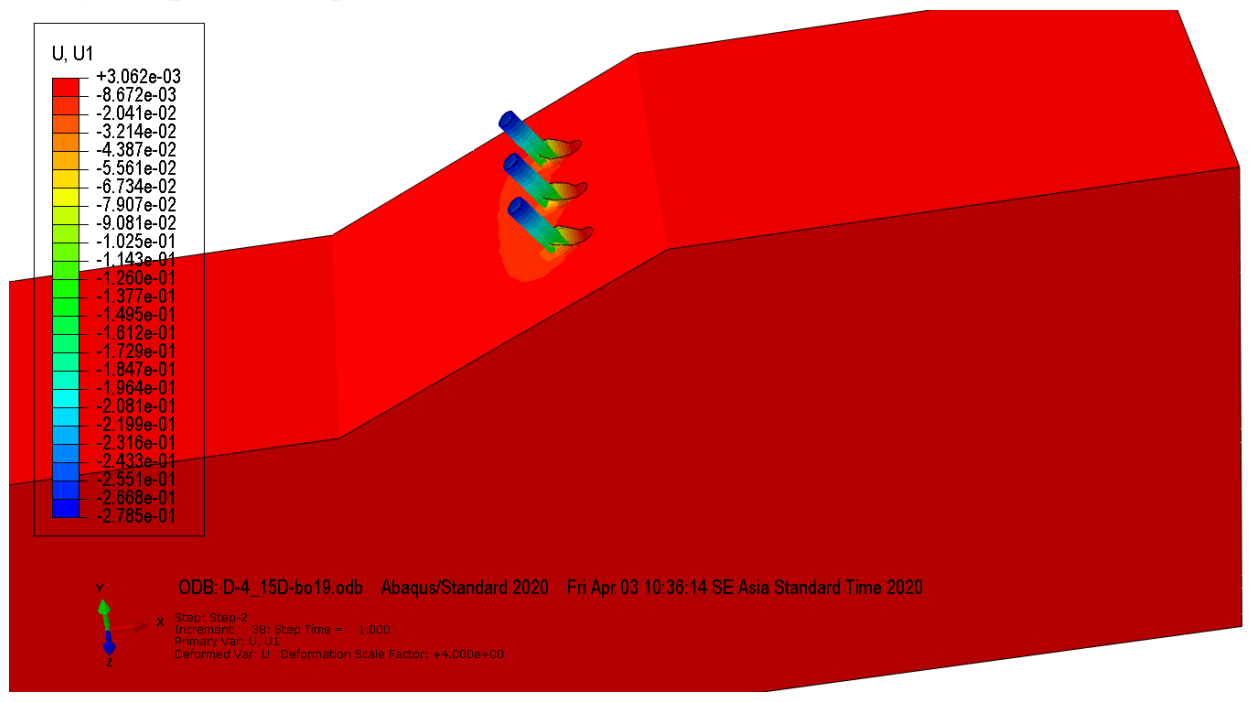

(b)

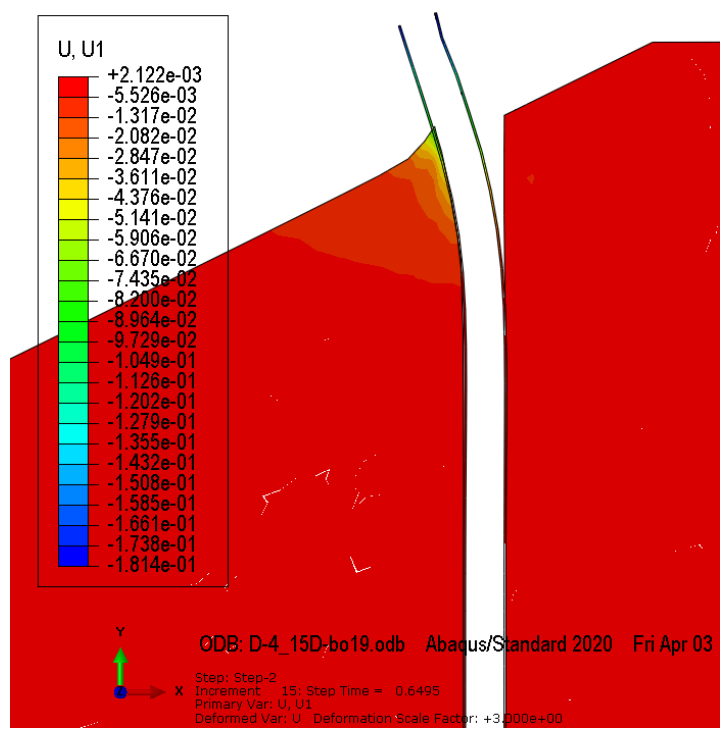

(c)

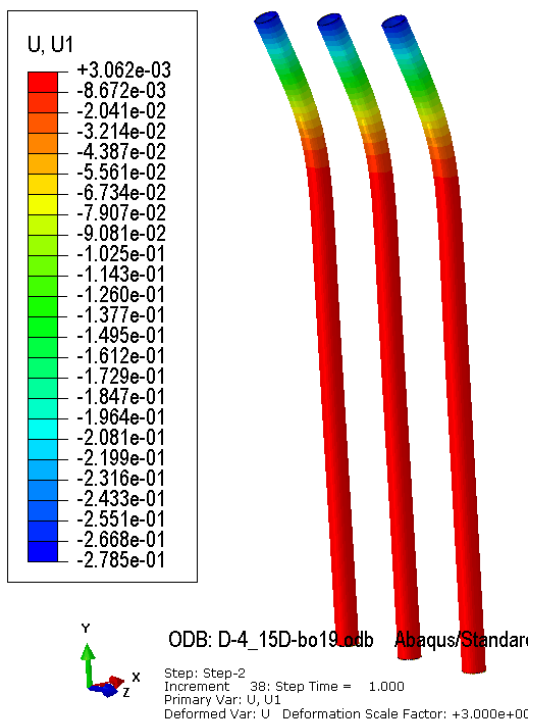

Figure 4. ABAQUS modelling views.

In addition, the slope performance influences the pile under lateral loading. Within this study the distance from pile centreline to slope crest is constance of $s=-4 \mathrm{D}$ for many cases of pile to pipe intervals, the effect of slope is not considered. However, the further study can investigate this effect based on the same manner. 


\section{CONCLUSION}

The numerical modeling of single pile and a row of three piles, namely external and centre pile on the slope of layered soil was investigated. The single pile problem was used to verify with the case of experiment case study of [11]. The good agreement obtained to allow the numerical modelling of the row pile.

The pile in row influences the performance of adjacent pile due to the movement of soil surrounding pile make the soil weaker than intact soil in single pile case.

In order to ensure no effect of adjacent pile when the row of pile subjected to lateral loading, the minimum distance between them should be four time the pile diameter. However, with the different soil slope, this minimum distance should be different from this case study.

\section{ACKNOWLEDGMENT}

Thanks to the Le Quy Don Technical University for their contribution to the research.

\section{REFERENCES}

[1]. ABAQUS 6.12 [Computer software], Providence, RI, SIMULIA.

[2]. F. A. Abdrabbo, K. E. Gaaver, Simplified analysis of laterally loaded pile groups, Alexandria Engineering Journal, 51 (2012) 121-127. https://doi.org/10.1016/j.aej.2012.05.005

[3]. D. A. Brown, C-F. Shie, Some numerical experiments with a three dimensional finite element model of a laterally loaded pile, Computers and Geotechnics, 12 (1991) 149-162. https://doi.org/10.1016/0266-352X(91)90004-Y

[4]. CALTRANS, Bridge design specifications manual, California Department of Transportation, USA, 2010.

[5]. K. S. Chae, K. Ugai, A. Wakai, Lateral resistance of short single piles and pile groups located near slopes, International Journal of Geomechanics, 4 (2004) 93-103. https://doi.org/10.1061/(ASCE)1532$\underline{3641(2004) 4: 2(93)}$

[6]. M. A. Gabr, R. H. Borden, Lateral analysis of piers constructed on slopes, Journal of Geotechnical Engineering, 116 (1990) 1831-1850. https://doi.org/10.1061/(ASCE)0733-9410(1990)116:12(1831)

[7]. K. Georgiadis, M. Georgiadis, Undrained Lateral Pile Response in Sloping Ground, Journal of Geotechnical \& Geoenvironmental Engineering, 136 (2010) 1489-1500. https://doi.org/10.1061/(ASCE)GT.1943-5606.0000373

[8]. K. Muthukkumaran, Effect of slope and loading direction on laterally loaded piles in cohesionless soil, International Journal of Geomechanics, 14 (2014) 1-7. https://doi.org/10.1061/(ASCE)GM.1943$\underline{5622.0000293}$

[9]. K. Muthukkumaran et al., Effect of Slope on P-Y Curves Due to Surcharge Load, Soils and foundations, 48 (2008) 353-361. https://doi.org/10.3208/sandf.48.353

[10]. C. W. W. Ng et al., Influence of laterally loaded sleeved piles and pile groups on slope stability. Canadian Geotechnical Journal, 38 (2001) 553-566. https://doi.org/10.1139/t00-109

[11]. N. Nimityongskul, Effects of Soil Slope on Lateral Capacity of Piles in Cohesive Soils, PhD Thesis, Oregon State University, USA, 2010.

[12]. V. Nguyen et al., Three dimensional numerical simulation to predict performance of laterally loaded piles on clay-sand layered slope, GeoMontreal, 2013.

[13]. A. S. Osman, M. F. Randolph, Analytical Solution for the Consolidation around a Laterally Loaded Pile, International Journal of Geomechanics, 12 (2012) 199-208. https://doi.org/10.1061/(ASCE)GM.1943-5622.0000123

[14]. H. G. Poulos, E. H. Davis, Pile foundation analysis and design. John Wiley, New York, 1980.

[15]. R. K. Rowe, H. G. Poulos, A method for predicting the effect of piles on slope behaviour, Research report in School of Civil Engineering, Sydney, Australia, 1979. 